\title{
PENGUATAN PENDIDIKAN KARAKTER HINDU DALAM YOGA UNTUK SISYA PASRAMAN AMERTA SANJIWANI
}

\section{STRENGTHENING HINDU CHARACTER EDUCATION IN YOGA FOR SISYA ON PASRAMAN AMERTA SANJIWANI}

\section{Wayan Agus Gunada ${ }^{1}$, Ida Bagus Kade Yoga Pramana², dan I Wayan Rudiarta ${ }^{3}$ \\ ${ }^{123}$ Institut Agama Hindu Negeri Gde Pudja Mataram, Mataram, Indonesia iwayanagusgunada@iahn-gdepudja.ac.id}

DOI: 10.31291/jlka.v19.i2.973

Diterima: 15 September 2021; Direvisi: 15 Desember 2021;

Diterbitkan: 31 Desember 2021

\begin{abstract}
The writing of this article aims to describe the results of yoga training activities in sisya pasraman and practice skills to strengthen the understanding of the essence of Hindu educational values. This study is qualitative with a case study approach on yoga training activities. Data collection techniques use participant observation models, interviews and document studies, which are analyzed using data triangulation techniques. Based on the results of the data analysis, sisya is very enthusiastic about learning the yoga movements given by the coaches. In addition to the process and concept of yoga, teachings contain character values, one of which is religious character and discipline, reflected in the teachings of morals, namely tri kaya parisudha, the concept of parhyangan, the teachings of panca Yama brata and panca nyama brata. Yoga training and writing activities of this article are expected to provide benefits in the form of resource development of Hindus of character and can become a reference library for relevant activities in the future.
\end{abstract}

Keywords: Hinduism, Character, Pasraman, Yoga. 


\begin{abstract}
ABSTRAK
Tulisan ini bertujuan untuk menggambarkan hasil kegiatan pelatihan yoga pada sisya pasraman selain melatih keterampilan juga untuk menguatkan pemahaman akan esensi nilai-nilai pendidikan Hindu. Kajian ini berjenis kualitatif dengan pendekatan studi kasus pada kegiatan pelatihan yoga. Adapun teknik pengumpulan data menggunakan model observasi partisipan, wawancara dan studi dokumentasi, yang dianalisis menggunakan teknik trianggulasi data. Berdasarkan hasil analisis data didapatkan bahwa sisya sangat antusias dalam mempelajari gerakangerakan yoga yang diberikan oleh para pelatih, di samping itu dalam proses dan konsepnya ajaran yoga mengandung nilai-nilai karakter salah satunya adalah karakter religius dan disiplin yang tercermin dalam ajaran susila yaitu tri kaya parisudha, konsep parhyangan dan ajaran panca yama brata dan panca nyama brata. Kegiatan pelatihan yoga dan penulisan artikel ini diharapkan dapat memberikan manfaat berupa pembangunan sumber daya umat Hindu yang berkarakter dan dapat menjadi pustaka rujukan bagi kegiatan yang relevan di masa depan.
\end{abstract}

Kata kunci: Hindu, Karakter, Pasraman, Yoga.

\title{
PENDAHULUAN
}

Pendidikan dewasa ini merupakan aktivitas yang dianggap sebagai rutinitas biasa namun dalam konteks esensi filosofis pendidikan merupakan proses yang sangat penting tidak hanya pada peningkatan intelektualitas semata namun lebih dalam adalah untuk menyiapkan masa depan, bukan hanya pada lingkup pekerjaan namun pada penyadaran akan hakikat diri dan pengembangan karakter. Pendidikan juga dapat dimaknai dan diartikan sebagai aktivitas serta proses yang bertujuan untuk membangun pengetahuan dan pengembangan kualitas diri serta untuk mendewasakan pemikiran ${ }^{1}$. Sedangkan dalam konsep agama Hindu, pendidikan lebih mengarah kepada pengembangan kualitas

${ }^{1}$ Zaim Elmubarok, Membumikan Pendidikan Nilai Mengumpulkan Yang Terserak, Menyambung Yang Terputus, Dan Menyatukan Yang Tercerai, ed. Dudung Rahmat Hidayat, 3rd ed. (Bandung: ALFABETA, 2013). 2-3 
manusia dari sisi moral dan perilaku, untuk membangun sumber daya Hindu yang berkarakter ${ }^{2}$.

Pendidikan keagamaan Hindu secara esensinya merupakan proses usaha pembelajaran diri, bukan hanya kepada pengembangan intelektualitas semata namun esensi yang terdalam adalah pengembangan perilaku yang berpedoman dengan nilai-nilai ajaran agama Hindu untuk membentuk inidividu yang berkarakter.

Permasalahan pendidikan dewasa ini tidak hanya sebatas pada proses pendidikan saja, namun secara fenomena adalah output dari proses pendidikan yang sedang berlangsung. Kemajuan ilmu pengetahuan dan perkembangan teknologi yang masif dewasa ini nyatanya juga berpengaruh pada proses pendidikan, namun kemajuan tersebut bukan hanya berdampak secara positif namun juga terdapat sisi negatif salah satunya penggunaan teknologi tidak tepat guna yang kemudian mengakibatkan mudahnya generasi muda untuk mengakses konten-konten negatif yang menyebabkan terjadinya kenakalan remaja. Perkembangan teknologi yang cukup signifikan nyatanya juga sangat memengaruhi generasi muda salah satunya mulai adanya pengikisan kesadaran berkaitan dengan kehidupan sosial $^{3}$, serta penggunaan media teknologi informasi salah satunya internet yang keliru juga memicu terjadinya perilaku remaja mengarah menuju ke hal negatif ${ }^{4}$.

Hal ini yang kemudian menjadi perhatian bahwa proses pendidikan perlu untuk dievaluasi, bukan hanya bagaimana efisiensi proses pendidikan dilakukan, namun mengembalikan kem-

${ }^{2}$ Setyaningsih, "Implementasi Pembelajaran Pendidikan Agama Hindu Dalam Pembentukan Karakter Anak Hindu Di Sekolah Dasar Negeri Surakarta," Cetta: Jurnal Ilmu Pendidikan 2, no. 2 (2019): 297-332, https://jayapanguspress.penerbit.org/index.php/cetta/article/view/272.

${ }^{3}$ Asniati Asniati, Sudarmi Suud Binasar, and Jahada Jahada, "Pengaruh Penggunaan Internet Terhadap Kenakalan Remaja (Siswa)," Jurnal Ilmiah Bening: Belajar Bimbingan Dan Konseling 4, no. 1 (2020): 17-26, https://doi.org/10.36709/bening.v4i1.10485.

${ }^{4}$ Riska Mayeni, Okviani Syafti, and Sefrinal, "Dampak Perkembangan Teknologi Dikalangan Remaja Dilihat Dari Nilai-Nilai Karakter," Turast: Jurnal Penelitian Dan Pengabdian 7, no. 2 (2019): 239-46, https://doi.org/ 10.15548/turast.v7i2.1298 
bali tujuan pendidikan untuk membentuk generasi yang berkarakter untuk dapat menjadi generasi penerus bangsa yang memegang teguh nilai-nilai moral Pancasila. Hal ini relevan dengan tujuan dari filsafat perenialisme bahwa nilai-nilai budaya lama yang mengandung konsep-konsep kebaikan baik dalam sisi kebudayaan ataupun moralitas yang berkembang di masyarakat, tentu harus diadaptasi untuk membentuk generasi yang baik, generasi yang memahami nilai-nilai dan esensi kebudayaannya ${ }^{5}$.

Fenomena ini yang kemudian menjadi salah satu alasan dalam pelaksanaan kegiatan pengabdian kepada masyarakat. Kegiatan ini juga bertujuan untuk membumikan dan mengimplementasikan nilai pendidikan dan konsep ajaran agama Hindu sebagai penguatan dan internalisasi karakter pada generasi muda Hindu sejak dini melalui kegiatan-kegiatan pelatihan dan pembelajaran keagamaan Hindu salah satunya adalah pelatihan Yoga. Karena fenomena yang menjadi realita dilapangan, mulai eksisnya kegiatan-kegiatan berkaitan dengan yoga, menjadikan yoga sebagai salah satu ikon dalam setiap kegiatan keagamaan Hindu. Bahkan dalam skala Nasional, yoga telah menjadi salah satu cabang kompetisi yang dilombakan khususnya pada kegiatankegiatan lomba bertemakan Hindu.

Yoga dewasa ini mengalami kenaikan pamor yang cukup luar biasa, bagaimana tidak yoga kini sudah tidak lagi memandang praktiknya hanya kepada umat Hindu saja namun juga yoga sudah mengikis sekat di mana kini kegiatan yoga juga diminati oleh umat agama lain6 ${ }^{6}$ Di satu sisi dengan mulai eksisnya kegiatan yoga yang dipandang sebagai gaya hidup dalam istilah olah raga tentu sangat memberikan dampak baik dengan dikenal luasnya yoga, namun disisi lain yoga malah hanya dikenal sebagai bagian dari aktivitas olah raga semata, tentu sangat berlawanan dalam konsep aslinya.

5 Nuryamin, "Implementasi Filsafat Perenial Dalam Pembelajaran," Jurnal Aqidah-Ta 5, no. 1 (2019): 49-61, https://doi.org/10.24252/ aqidahta. v5i1.7884.

${ }^{6}$ I Wayan Budi Utama and Ida Bagus Suatama, "Ketika Yoga Sebagai Gaya Hidup," Dharmasmrti: Jurnal Ilmu Agama Dan Kebudayaan 18, no. 1 (2018): 16-24, https://doi.org/10.32795/ds.v1i18.111. 
Istilah yoga memiliki makna proses menghubungkan dan menyatukan ${ }^{7}$, kesatuan antara badan jasmani dengan jiwa rohani melalui serangkaian gerakan-gerakan dinamis untuk mengolah rasa, raga dan pikiran yang secara konseptual dan esensial penyatuan jiwa manusia dengan jiwa alam semesta yaitu Brahman ${ }^{8}$. Ini mengindikasikan bahwa yoga bukan hanya sekedar gerakangerakan dinamis biasa, namun terkandung esensi dan konsep spiritualitas karena tujuan dari yoga bukan hanya kesehatan fisik semata, namun juga mental serta spiritual ${ }^{9}$. Di mana secara spiritual tujuan yoga adalah menyatukan atman dengan paramatman. Sehingga ketika esensi yoga sebagai pelatihan diri melalui jalan spiritual, maka di dalamnya terkandung nilai-nilai agama salah satunya ajaran susila yang berpedoman kepada ajaran agama Hindu.

Pelatihan yoga yang dilakukan di Pasraman Amerta Sanjiwani yang memfokuskan kegiatan pada anak-anak bukan hanya sekedar kegiatan pelatihan dan pengenalan gerakan yoga semata, namun secara konseptual adalah penanaman ajaran etika, moral dan spiritual sejak dini sehingga anak-anak tidak lagi memparadigmakan yoga hanya sebagai gerakan senam biasa namun terkandung konsepsi ajaran agama Hindu yang luhur di dalamnya.

Pada beberapa hasil analisis pustaka sebelumnya yang digunakan sebagai kajian pustaka berkaitan dengan penulisan artikel ini disebutkan bahwa yoga sangat membantu mempertahankan kualitas hidup melalui perangsangan syarafsyaraf yang terdapat dalam tubuh sehingga sangat membantu

${ }^{7}$ Arum Sukma Kinasih, "Pengaruh Latihan Yoga Terhadap Peningkatan Kualitas Hidup," Buletin Psikologi 18, no. 1 (2010): 1-12, https://doi.org/ 10.22146/bpsi.11531.

${ }^{8}$ Ketut Wendi Astuti, "Olah Raga, Olah Rasa Dan Olah Pikiran Melalui Asana Yoga,” Jurnal Bakti Saraswati Vol. 08, no. 02 (2019): 179-91, https://e-journal.unmas.ac.id/index.php/baktisaraswati/article/view/617.

9I Ketut Madja, "Makna Astangga Yoga Patanjali," Guna Widya: Jurnal Pendidikan Hindu 7, no. 1 (2020): 87-96, https://doi.org/10.25078/ gw.v7i1.1278. 
menjaga kesehatan organ-organ vital dalam diri ${ }^{10}$. Surya Namaskara sebagai salah satu jenis yoga dalam prosesnya sangat membantu untuk menjaga serta memberikan manfaat dalam menguatkan fisik, mental, spiritual dan membentuk kelenturan organ paru-paru jika dilakukan secara rutin ${ }^{11}$. Kegiatan yoga yang dilakukan secara rutin juga sangat membantu dalam menurunkan lemak tubuh, serta terdapat korelasi antara aktivitas yoga dengan kapasitas organ paru dengan penurunan lemak tubuh $^{12}$. Selanjutnya disebutkan bahwa keberadaan yoga dalam praktiknya harus dilakukan secara bertahap, karena proses dalam aktivitasnya tidak dilaksanakan secara instan, tahap-tahap dalam prosesnya adalah melatih tubuh, melatih pikiran untuk mampu mengendalikan indriya sehingga tujuan akhir adalah penyatuan kepada Brahman ${ }^{13}$. Proses aktivitas yoga yang dilakukan dengan diawali doa merupakan serangkaian aktivitas untuk penanaman konsep-konsep spiritualitas, implikasi dalam pelaksanaannya adalah untuk memotivasi anak-anak dalam belajar menjadi lebih baik, sehingga terdapat korelasi antara pelatihan yoga sebagai pembangunan spiritualitas bagi anak-anak dalam proses belajar $^{14}$.

Berdasarkan hasil analisis terhadap beberapa kajian pustaka maka dapat disimpulkan bahwa aktivitas yoga dalam praktiknya sangat membantu untuk menjaga kualitas tubuh, bukan hanya pada kesehatan tubuh namun juga kesehatan mental dan spritual, pelatihan yoga untuk mendapatkan manfaatnya tidak

\footnotetext{
${ }^{10}$ Kinasih, "Pengaruh Latihan Yoga Terhadap Peningkatan Kualitas Hidup.”. 1-12

${ }^{11}$ Ketut Mertayasa, "Pengaruh Pelatihan Yoga Asana (Suryanamaskar) Terhadap Kelentukan Dan Kapasitas Vital Paru," Ilmu Keolahragaan Undiksha 1, no. 1 (2013): 1-8, https://doi.org/10.23887/jiku.v1i1.1578.

${ }^{12}$ Gilang Nuari Panggraita, Sugiharto, and Tommy Soenyoto, "Pengaruh Latihan Hatha Yoga Dan Kapasitas Vital Paru Terhadap Penurunan Lemak Tubuh," Journal of Physical Education and Sports 6, no. 1 (2017): 29-35, https://doi.org/10.15294/jpes.v6i1.17318.

${ }^{13}$ I Nyoman Dayuh, "Pengetahuan Spiritual Yoga," Jurnal Penjaminan Mutu 1, no. 2 (2016): 79-90, https://doi.org/10.25078/jpm.v1i2.53.

${ }^{14}$ Heny Perbowosari, "Optimalisasi Kecerdasan Spiritual Anak Melalui Yoga Asanas,” Kamaya: Jurnal Ilmu Agama 1, no. 2 (2018): 166-77, https:// jayapanguspress.penerbit.org/index.php/kamaya/article/view/77.
} 
hanya dilakukan secara sembarangan, namun harus dilakukan secara bertahap karena manfaat yang dihasilkan dalam praktik yoga tidak serta merta terjadi secara instan, terdapat pula korelasi antara pelatihan yoga dengan peningkatan spiritualitas bagi anakanak untuk membantu memfokuskan dan memotivasi anak dalam belajar. Oleh karenanya secara teoretis, relevansi dan persamaannya maka hasil artikel terdahulu memberikan penguatan konsep terkait penulisan artikel yang dilakukan sekarang.

Perbedaannya terletak pada tujuan bahwa implikasi yang diharapkan dalam pelatihan yoga bagi anak-anak di Pasraman Amerta Sanjiwani tidak hanya untuk pengembangan kesehatan tubuh semata, namun juga untuk menginternalisasi nilai-nilai karakter, sehingga anak-anak di pasraman memiliki visi dan karakter untuk mengembangkan pengetahuan, sikap dan keterampilannya untuk membangun sumber daya umat Hindu yang unggul dan berkarakter bukan hanya saat belajar di Pasraman, namun juga tetap melaksanakan bentuk-bentuk perilaku yang sesuai dengan ajaran susila Hindu baik di rumah dalam lingkungan keluarga dan dimasyarakat. Hal ini untuk memberikan pemahaman bahwa pembentukan karakter melalui pelatihan yoga, bukan hanya harus dipraktikkan dalam kehidupan belajar di pasraman namun pada ruang lingkup yang lebih luas yaitu di keluarga dan di masyarakat.

Secara empiris dalam proses kegiatan pelatihan yoga yang diadakan ini dan dilakukan di salah satu Pasraman yang berlokasi di daerah Rincung, Kabupaten Lombok Barat. Pasraman tersebut adalah Pasraman Amerta Sanjiwani dengan sasaran pelatihan adalah anak-anak peserta didik pasraman serta beberapa anak-anak dan remaja yang berada di kawasan sekitar pasraman. Jumlah anak-anak yang mengikuti pelatihan berjumlah 40 orang anak usia sekolah. Tempat pelaksanaan dilakukan di Balai Banjar setempat, dengan menggunakan sarana matras. Lokasi ini dipilih dikarenakan merupakan pasraman yang cukup sering dan aktif dalam melaksanakan kegiatan-kegiatan pasraman. Di samping juga, pasraman yang berlokasi di daerah Lombok Barat dengan jumlah umat Hindu bukan mayoritas 
dibandingkan dengan umat agama lain, tentu keberadaannya menjadi penting sebagai lembaga pendidikan keagamaan yang bertujuan untuk menguatkan sradha dan bhakti umat Hindu terutama generasi muda, utamanya tantangan dalam hidup bermasyarakat yang plural sehingga dapat hidup berdampingan secara damai dan harmonis dengan pemeluk agama lain dalam kehidupan moderasi beragama.

Penulisan artikel ini menggunakan pendekatan kualitatif dengan mengaplikasikan model pendekatan dengan studi kasus, karena penulisan artikel ini dilakukan pada kegiatan pelatihan yoga sebagai implementasi keilmuan yang dilaksanakan secara teprogram oleh Prodi Pendidikan Agama Hindu di Pasraman Amerta Sanjiwani. Istilah studi kasus mengacu ke dalam jenis pendekatan kualitatif yang menekankan kepada eksplorasi dan identifikasi suatu peristiwa dalam satu waktu ${ }^{15}$. Konsep artikel dengan pendekatan studi kasus cenderung untuk mengkaji sebuah pemahaman berkaitan dengan peristiwa ${ }^{16}$, dan konteks studi kasus juga untuk menganalisis fenomena pada kehidupan nyata $^{17}$. Pemilihan model studi kasus dikarenakan penulisan artikel ini mengkaji kegiatan pelatihan yoga yang berlangsung selama kegiatan dilakukan.

Data dikumpulkan menggunakan teknik observasi partisipan, wawancara dan studi dokumen. Observasi partisipan merupakan kegiatan pengamatan yang dilakukan di mana pengamat ikut serta secara langsung dalam peristiwa yang sedang diteliti dan dikaji ${ }^{18}$. Wawancara dilakukan dengan mengadakan dialog

${ }^{15}$ John W. Creswell, Penelitian Kualitatif Dan Desain Riset Memilih Di Antara Lima Pendekatan, ed. Saifuddin Zuhri Qudsy, 3rd ed. (Yogyakarta: Pustaka Pelajar, 2015). 169-168

${ }^{16}$ Ratna Dewi Nur'aini, "Penerapan Metode Studi Kasus Yin Dalam Penelitian Arsitektur Dan Perilaku," INERSIA: Lnformasi Dan Ekspose Hasil Riset Teknik Sipil Dan Arsitektur 16, no. 1 (2020): 92-104, https://doi.org/ 10.21831/inersia.v16i1.31319.

${ }^{17}$ Unika Prihatsanti, Suryanto Suryanto, and Wiwin Hendriani, "Menggunakan Studi Kasus Sebagai Metode Ilmiah Dalam Psikologi," Buletin Psikologi 26, no. 2 (2018): 126-36, https://doi.org/10.22146/ buletinpsikologi.38895.

${ }^{18}$ Emzir, Metodologi Penelitian Kualitatif Analisis Data, 1st ed. (Jakarta: Rajawali Press, 2014). 39 
dan diskusi dengan beberapa narasumber diantaranya Ketua Pasraman Amerta Sanjiwani, beberapa Acarya yang mengajar di Pasraman, sisya yang merupakan peserta pelatihan dan beberapa anggota masyarakat, dan juga melakukan studi dokumentasi yang dilakukan dengan melaksanakan analisis berkaitan hasil dokumentasi baik foto ataupun pustaka-pustaka yang relevan berkaitan dengan tema artikel ${ }^{19}$.

Setelah data dikumpulkan maka proses selanjutnya adalah melaksanakan analisis data untuk mengolah data mentah yang didapatkan, proses ini dilakukan dengan menggunakan teknik analisis Miles dan Huberman berupa proses pemilihan data, setelah dipilah data kemudian disajikan dan dipolakan kemudian diverifikasi, serta data dianalisis secara mendalam dengan teknik triangulasi sumber dan model diskusi teman sejawat yang pakar pada bidangnya ${ }^{20}$.

Secara pragmatis tujuan dari artikel ini khususnya pelatihan yoga adalah merupakan implementasi keilmuan prodi Pendidikan Agama Hindu sebagai pelaksanaan dharma ketiga dalam Tri Dharma Perguruan Tinggi. Tujuan kedua adalah bentuk tanggung jawab lembaga dalam menyebarkan konsepkonsep keilmuan lembaga dalam rangka memberikan perhatian kepada umat sehingga ikut memberikan sumbangsih terhadap pembangunan kualitas sumber daya umat Hindu. Tujuan ketiga adalah menganalisis, mengkaji dan membumikan nilai-nilai karakter dalam ajaran Yoga, sehingga anak-anak memiliki pengetahuan yang komprehensif mengenai apa itu yoga dan esensinya, serta untuk menginternalisasi nilai-nilai susila dalam konsep ajaran yoga untuk membangun siswa pasraman yang unggul dan berkarakter Hindu dalam peningkatan sradha dan bhakti.

Manfaat dalam artikel ini berdasarkan kegiatan pelatihan yoga adalah untuk memberikan gambaran proses pelaksanaan

${ }^{19}$ Sugiyono, Metode Penelitian Kuantitatif, Kualitatif Dan $R \& D, 1$ st Ed. (Bandung: ALFABETA, 2016). 240

${ }^{20}$ Sugiyono, Metode Penelitian Kualitatif Untuk Penelitian Yang Bersifat: Eksploratif, Enterpretif, Interaktif Dan Konstruktif, ed. Sofia Yustiyani Suryandari, 1st ed. (Bandung: ALFABETA, 2020). 125-127 
kegiatan pelatihan yoga, serta analisis nilai-nilai pendidikan karakter Hindu yang terkandung di dalamnya, sehingga dapat menjadi pustaka rujukan dalam kegiatan-kegiatan pengkajian dan pengabdian selanjutnya. Serta memberikan penguatan dan penambahan wawasan mengenai esensi yoga bagi umat Hindu, baik teori, praktik dan manfaat yoga itu sendiri.

\section{HASIL DAN PEMBAHASAN}

Fokus permasalahan pada artikel ini berkaitan dengan kegiatan pelatihan Yoga pada anak-anak Pasraman Amerta Sanjiwani ini adalah bagaimana desain pelatihan dan nilai-nilai karakter Pendidikan Agama Hindu yang terkandung di dalam konsep dan esensi Yoga. Berdasarkan hasil analisis terkait temuan data, maka dapat dijelaskan sebagai berikut:

\section{Desain Pelatihan Yoga Bagi Anak-Anak Pasraman Amerta Sanjiwani}

Berdasarkan hasil analisis data terkait dengan desain pelatihan kegiatan Yoga ini, maka konsep desain pelatihan mengacu kepada desain instruksional atau dalam istilah umum dikenal dengan desain pembelajaran. Desain Pembelajaran merupakan seperangkat aktivitas perancangan keseluruhan proses belajar mengajar yang meliputi tahap perencanaan, hingga tahap perancangan proses pengukuran hasil desain dan hasil belajar di mana dalam perancangannya melibatkan berbagai sudut pandang dan unsur serta keahlian pendidik ${ }^{21}$. Secara konseptual dalam proses perancangan sebuah desain pembelajaran terdapat berbagai jenis model instruksional desain yang memiliki kelebihan dan kekurangan, serta dampaknya dalam proses pembelajaran, namun secara esensial jika mengacu kepada jenis-jenis model tersebut terdapat kesamaan yang relevan yaitu adanya analisis tujuan instruksional, pemilihan media dan metode pembelajaran, peng-

${ }^{21}$ Punaji Setyosari, Desain Pembelajaran, ed. Bunga Sari Fatmawati, 1st ed. (Jakarta: PT Bumi Aksara, 2020). 18-19 
embangan materi, perancangan proses pelaksanaan belajar dan evaluasi ${ }^{22}$.

Berdasarkan hal tersebut berkaitan dengan kegiatan pelatihan Yoga ini maka dapat digambarkan sebagai berikut:

1. Analisis Instruksional Umum, ini mengacu kepada pengkajian tujuan pembelajaran yang diharapkan untuk terwujud dalam proses pembelajaran, adapun secara umum maka tujuan dalam kegiatan ini agar anak-anak Pasraman memahami konsep serta esensi dari kegiatan Yoga dalam ajaran agama Hindu. Berkaitan dengan sikap, diharapkan melalui kegitan pelatihan yoga ini anak-anak mampu memberikan respon yang baik untuk dapat mengapresiasi makna yoga sehingga terbentuk perilaku menghargai ajaran-ajaran agama Hindu dalam rangka pengembangan karakter. Berkaitan dengan keterampilan, diharapkan anak-anak pasraman mampu untuk terampil dalam melakukan gerakan-gerakan yoga.

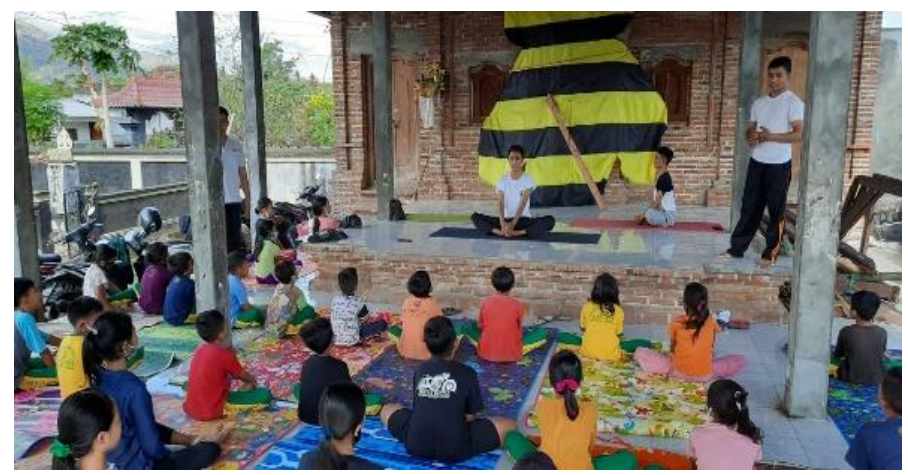

Sumber: Dokumentasi Tim Pengabdian, 2021

Gambar 1.

Penjelasan Mengenai konsep dalam gerakan Yoga

2. Pemilihan media, strategi dan metode pelatihan. Berkaitan dengan media maka dalam kegiatan yoga ini media menggunakan media audio melalui sound system, adapun strategi

${ }^{22}$ Khoe Yao Tung, Desain Instruksional Perbandingan Model Dan Implementasinya, ed. Venan, 1st ed. (Yogyakarta: ANDI, 2017). 1 
dan metode pelatihan menggunakan pendekatan ceramah untuk menjelaskan konsep-konsep yoga seperti terlihat pada Gambar 1. dan praktik langsung melalui demonstrasi dan pembimbingan secara langsung yang terlihat pada Gambar 2, 3, 4 dan 5 .

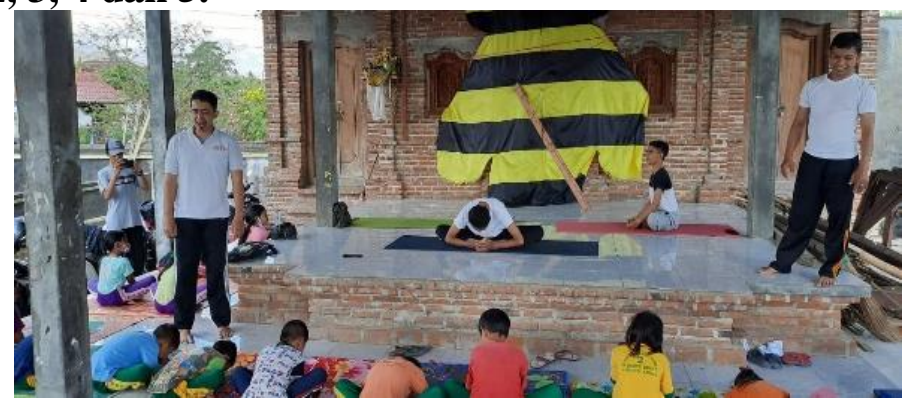

Sumber: Dokumentasi Tim Pengabdian, 2021

\section{Gambar 2.}

Demonstrasi gerakan Yoga oleh Instruktur dengan gerakan sederhana

3. Pengembangan materi, berkaitan dengan hal ini maka yang dimaksud adalah bahan ajar. Melihat karakteristik dan kebutuhan peserta pelatihan yang masih anak-anak sehingga materi didasarkan atas konsep-konsep sederhana seperti apa itu yoga, maknanya, gerakan-gerakan yoga sederhana dan tujuan serta manfaat dalam melaksanakan aktivitas Yoga.

4. Perancangan susunan pelaksanaan pelatihan, ini mengacu kepada bagaimana proses pelatihan dilakukan. Kegiatan pelatihan yoga dilaksanakan dengan pertama mempersiapkan peserta pelatihan, memberikan salam, perkenalan Instruktur, pemberian materi singkat, praktik yoga, demonstrasi yoga oleh instruktur, pembimbingan dan pendampingan serta refleksi kegiatan oleh peserta pelatihan bersamasama dengan instruktur. 


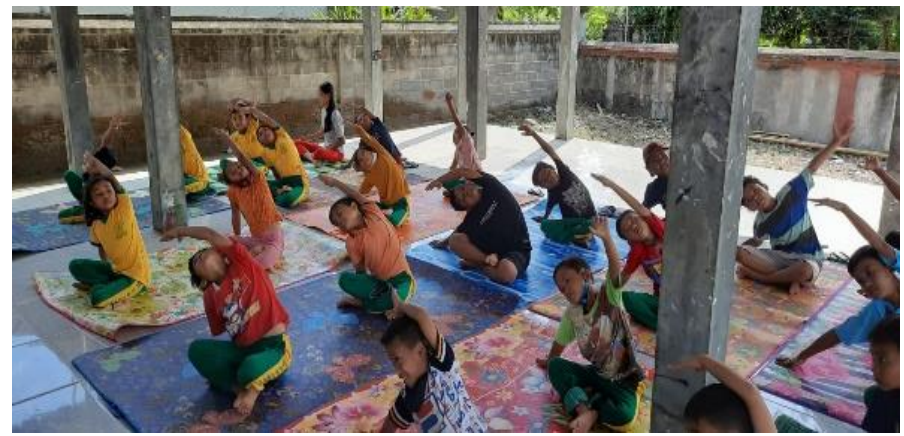

Sumber: Dokumentasi Tim Pengabdian, 2021

Gambar 3.

Tahap Pemanasan sebelum melaksanakan gerakan yoga

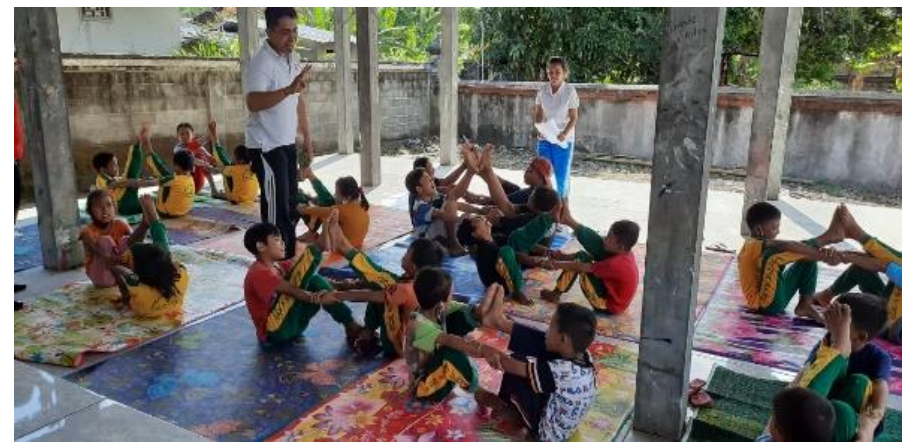

Sumber: Dokumentasi Tim Pengabdian, 2021

Gambar 4.

Pembimbingan secara Langsung oleh Instruktur

5. Tahap evaluasi desain dan evaluasi pelatihan. Berdasarkan hasil perancangan tahap demi tahap maka desain pelatihan dapat diaplikasikan dalam proses pelatihan dengan mempertimbangkan dan menyesuaikan kembali dengan situasi di lokasi pelatihan. Evaluasi pelatihan dilakukan dengan penilaian melalui pengamatan secara langsung terhadap peserta pelatihan untuk melihat apakah peserta pelatihan sudah mampu melaksanakan gerakan yoga dan diskusi dalam proses refleksi untuk melihat apakah peserta pelatihan sudah memahami berkaitan dengan konsepsi yoga dalam ajaran agama Hindu. Evaluasi juga digunakan untuk mengukur dan menilai apakah pemahaman mengenai konsepsi yoga yang 
telah diketahui oleh para sisya telah memberikan pengaruh dalam membentuk karakter sesuai ajaran agama Hindu dengan mengamati perilaku yang terjadi selama proses pelatihan.

\section{Pendidikan Karakter dalam Tata Susila Hindu melalui Pelatihan Yoga Bagi Anak-Anak Pasraman Amerta Sanjiwani}

Pengertian Karakter memiliki sejumlah definisi yang memberikan makna apa sebenarnya karakter itu. Karakter dalam pemaknaannya merupakan situasi dalam diri yang merupakan korelasi antara fisiologis dan psikologis yang menjadi ciri pembeda akan dirinya dengan orang lain ${ }^{23}$. Karakter dalam pendidikan mengacu sebagai harapan akhir dari proses pendidikan untuk pengembangan sumber daya, karakter merupakan hasil dari moralitas yang dilandasi oleh budi, di mana moralitas ini merupakan nilai-nilai kebaikan yang diharapkan terbangun dalam diri manusia ${ }^{24}$. Karakter merupakan ciri kepribadian yang merupakan hasil berbagai proses dalam diri manusia, penguatan nilai-nilai etika dan moralitas yang baik sejak anak-anak maka akan membuat anak tersebut memiliki karakter yang baik sehingga tidak akan mudah terpengaruh oleh unsur-unsur eksternal yang tidak baik ${ }^{25}$. Berdasarkan definisi-definisi tersebut, maka konsep karakter berpedoman kepada ciri khas yang tampak yang diperlihatkan oleh individu yang sangat dipengaruhi baik secara internal ataupun eksternal.

Berkaitan dalam agama Hindu maka konsep karakter yang bersumber dari moralitas memiliki makna konsep yang bersumber dari ajaran-ajaran agama Hindu. Moral secara makna kata memiliki arti seperangkat ide atau gagasan mengenai tindakan

${ }^{23}$ Abdul Jalil, "Karakter Pendidikan Untuk Membentuk Pendidikan Karakter," Nadwa: Jurnal Pendiidkan Islam 6, no. 2 (2012): 175-93, https://doi.org/10.21580/nw.2012.6.2.586.

${ }^{24}$ Muhammad Sulhan, "Pendidikan Karakter Berbasis Budaya Dalam Menghadapi Tantangan Globalisasi," Visipena Journal 9, no. 1 (2018): 15972, https://doi.org/10.46244/visipena.v9i1.450.

${ }^{25} \mathrm{Ni}$ Made Sukerni, "Pendidikan Karakter Dalam Lontar Tutur Silakramaning Aguron-Guron," Guna Widya: Jurnal Pendidikan Hindu 4, no. 1 (2017): 81-90, https://doi.org/10.25078/gw.v4i1.391. 
yang baik dan tidak baik ${ }^{26}$. Mengacu kepada pemahaman apa itu moralitas dalam Hindu, maka konsep mengenai tindakan baik yaitu subhakarma dan tidak baik yaitu asubha karma yang bersumber dari ajaran agama Hindu yaitu susila.

Ajaran agama Hindu yaitu tata susila atau susila memiliki esensi pengendalian terhadap tindakan yang akan dilakukan, pengendalian diri ini bersumber oleh etika-etika yang mengacu kepada ajaran agama Hindu, sehingga melalui pengendalian terhadap tindakan dan perilaku yang akan dilakukan menyebabkan terhindarnya diri dari hal-hal yang tidak diinginkan ${ }^{27}$.

Yoga sebagai salah satu ajaran agama Hindu tentu secara konseptual merupakan ajaran yang mengandung kesucian spiritualitas, dikarenakan secara esensi yoga merupakan suatu perwujudan usaha dan tindakan yang mengarah kepada penyatuan antara atman dengan jiwatman, sumber dari alam semesta. Sehingga tujuan yang suci tersebut, tentu didasarkan atas usaha dan melalui tindakan yang baik bersumber dari ajaran agama Hindu.

Yoga bukan hanya sekadar aktivitas olah raga, namun secara konseptual di dalamnya terkandung tujuan suci dan ajaranajaran susila yang suci pula, karena tujuan dari pendidikan keagamaan Hindu bukan hanya pengasahan keahlian untuk membantu hidup secara jasmaniah semata, namun juga tujuan tertinggi dari pendidikan keagamaan Hindu adalah terbentuknya pemahaman dan kesadaran akan hakikat manusia itu sendiri ${ }^{28}$. Oleh karenanya dalam yoga khususnya pelatihan yoga bagi anakanak Pasraman Amerta Sanjiwani ini terdapat tujuan penanaman

${ }^{26}$ Ilham Hudi, "Pengaruh Pengetahuan Moral (Moral Knowing) Terhadap Perilaku Moral (Moral Action) Pada Siswa SMP Negeri Kota Pekanbaru Berdasarkan Pendidikan Orangtua," Jurnal Moral Kemasyarakatan 2, no. 1 (2017): 30-44, https://doi.org/10.21067/ jmk. v2i1.1698.

${ }^{27}$ I Ketut Sudarsana, “Ajaran Satya Dan Dharma Dalam Membentuk Karakter Keluarga Hindu Di Desa Peguyangan Kangin Kota Denpasar," JSSH (Jurnal Sains Sosial Dan Humaniora) 2, no. 2 (2018): 289-302, https://doi.org/10.30595/jssh.v2i2.2188.

${ }^{28}$ Wayan Paramartha and I Wayan Suka Yasa, "Mengungkap Model Pendidikan Hindu Bali Tradisional Aguron-Guron," Mudra 32, no. 1 (2017): 131-40, https://doi.org/10.31091/mudra.v32i1.92. 
dan pemahaman konsep-konsep susila yang bersumber dari ajaran yoga itu sendiri, yaitu:

\section{Ajaran dan konsep Susila Tri Kaya Parisudha dalam Yoga.}

Moralitas merupakan suatu konsep yang membahas mengenai mana perilaku yang baik dan tidak baik ${ }^{29}$. Tri Kaya Parisudha merupakan salah satu ajaran luhur dan suci dalam konsep tata susila Hindu. Ajaran tri kaya parisudha mengajarkan bahwa untuk mencapai kesucian dalam diri harus menyeimbangkan tiga dasar dalam berperilaku. Landasan berperilaku tersebut terdiri dari tiga hal yaitu berpikir, berbicara dan berperilaku baik, di mana jika ketiga hal ini dilakukan maka akan membawa kesucian baik lahir dan batin ${ }^{30}$. Tri kaya parisudha terdiri dari kayika parisudha yaitu berbuat baik, wacika parisudha yaitu berbicara baik serta manacika parisudha yaitu berpikir yang baik ${ }^{31}$.

Yoga sebagai sebuah aktivitas, dan yoga sebagai sebuah jalan dalam ajaran agama Hindu harus dilakukan secara bertahap dan teratur, ini dilakukan untuk mendapatkan secara keseluruhan manfaat dari yoga berupa ketenangan pikiran, kesehatan tubuh, sehingga dengan sehat tubuh dan sehat pikiran maka inilah tujuan pertama dari yoga, maka dalam proses pelatihan yoga maka tubuhlah yang dilatih pertama setelah itu melatih pikiran melalui pengendalian indriya untuk membangun kesucian dalam $\operatorname{diri}^{32}$.

Yoga sebagai jalan spiritualitas tidak membuat manusia menjadi individu yang anti sosial dengan segala individualisme

${ }^{29}$ Gordon Graham, Teori-Teori Etika, ed. Muhammad Rizal, 1st ed. (Bandung: Nusa Media, 2014). 10-11

${ }^{30}$ Gek Diah Desi Sentana, "Penanaman Konsep Tri Kaya Parisudha Dalam Tradisi Mareraosan," Guna Widya: Jurnal Pendidikan Hindu 4, no. 2 (2017): 33-39, https://doi.org/10.25078/gw.v4i2.1056.

${ }^{31}$ Ni Made Sukrawati, "Nilai Didaktis Upacara Pacaruan Sasih Kaenem Di Pura Pasek Ngukuhin, Desa Pakraman Tonja, Kota Denpasar," Dharmasmrti: Jurnal Ilmu Agama Dan Kebudayaan 17, no. 2 (2017): 86-97, https://doi.org/10.32795/ds.v17i02.94.

${ }^{32}$ Perbowosari, “Optimalisasi Kecerdasan Spiritual Anak Melalui Yoga Asanas.”. 166-77 
yang ada dalam dirinya, namun spiritualitas dalam yoga adalah untuk membangun kesucian, lepas dari kekangan duniawi namun tidak meninggalkan sisi kemanusiaan ${ }^{33}$. Sehingga melalui jalan spiritualitas yang tidak menganggap diri paling benar dan tidak meninggalkan konsep-konsep kemanusian dalam diri inilah yang menjadi tujuan dalam yoga itu sendiri. Karena untuk membangun kesucian maka tubuh dan pikiran sebagai wadah atman disucikan, untuk mencapai spiritualitas yang sejati yaitu kesadaran akan hakikat semesta.

Kesucian yang diperoleh tentu tidak hanya dilakukan dengan melaksanakan ritual-ritual semata, namun dalam yoga kesucian dilakukan dengan melatih tubuh melalui penghindaran terhadap tindakan-tindakan perilaku yang tidak baik, dan melatih pengendalian pikiran untuk mengekang indriya-indriya liar dalam tubuh manusia.

Dalam Bhagawad Gita V. 28 disebutkan bahwa:

"yatendriya-mano-buddhir munir mokșa-parāyaṇah, vigetecchābhaya-krodho yah sadā mukta eva sah"

Artinya :

"Menguasai panca indria, pikiran dan kecerdasan, seorang Muni yang berhasrat mencapai kelepasan, membuang jauh nafsu, takut dan murka, mereka akan mencapai kelepasan yang abadi ${ }^{34}$.

Kemudian lebih lanjut dalam Bhagawad Gita VI. 4 disebutkan bahwa:

"Yadā hi nendriyārtheșu na karmasv anușajjate, sarva-sañkalpasañnyāsī yogārụ̈̂has tadocyate"

Artinya :

"Bila merasa benar-benar bebas dari ikatan obyek panca indra atau kegiatan kerja, dan mereka melepaskan segala niat keinginan, maka ia dikatakan mencapai yoga ${ }^{35}$ ".

${ }^{33}$ Dayuh, "Pengetahuan Spiritual Yoga.”. 79-90

${ }^{34}$ M Pudja, Bhagawad Gìtā (Pañcama Veda), ed. I Wayan Maswinara, 1st ed. (Surabaya: Paramita, 2013). 151

${ }^{35}$ Pudja. 155 
Petikan sloka di atas memberikan pemahaman bahwa pengendalian indriya dalam membangun kesucian dalam diri begitu penting utamanya dalam konsep-konsep yoga, sehingga kesucian melalui pengendalian pikiran serta perilaku kebaikan berdasarkan ajaran Dharma dalam agama Hindu inilah yang nantinya akan membawa pada hakikat keutamaan sebagai manusia dan kebahagian sebagaimana yang tertulis dalam kitab Sarasmusccaya sloka 14 berikut:

"ikang dharma ngaranya, henu ning mara ring swarga ika, kadi gati ning parahu, an henu ning banyaga nentas ing tasik".

Terjemahan :

"Yang disebut dharma adalah merupakan jalan untuk pergi ke sorga, sebagai halnya perahu yang merupakan alat bagi nelayan untuk mengarungi samudera ${ }^{36 "}$.

Berdasarkan kutipan sloka di atas maka dapat disimpulkan bahwa kesucian melalui implementasi ajaran agama Hindu sebagai ajaran dharma yang akan membawa kebahagian manusia, kebahagiaan bukan hanya pada jasmani namun juga rohani.

Sehingga melalui pembangunan kesucian dalam melatih tubuh untuk menyehatkan jasmani dan pengendalian pikiran untuk menyehatkan rohani maka dilakukan melalui konsepkonsep pelaksanaan tri kaya parisudha. Dalam sisi etika, tri kaya parisudha adalah pedoman berperilaku yang mengajarkan kepada manusia bahwa kebahagiaan dan kesucian akan didapatkan melalui perilaku yang baik, perilaku yang baik dari berkata, berbuat dan berpikir yang baik akan membangun interaksi yang baik kepada sesama manusia sehingga ketika terjadi interaksi dan hubungan yang harmonis maka akan terbentuk kehidupan yang baik.

Lebih dalam, lontar Siwa Sasana menyebutkan bahwa ;

${ }^{36}$ I Nyoman Kadjeng and dkk, Sarasamuscaya Dengan Teks Bahasa Sansekerta Dan Jawa Kuna, 1st ed. (Surabaya: Paramita, 1997). 
"Kuněng sadananing mamagēhana riya, hana sanghyang trikaya paramārtha, nga. Gĕgěn sang sādhaka, lwirnya nihan: kāyikā wacīkascewa, manasikas tratiyaka, śubha karmma niyowyantu, trikayamiti kawyate. Trikaya, nga, kāya wwang manah kāya, śarīra wak, nga, śabda, mana, nga, amběk, ika ta katiga pinasangakĕn manutang dharmma karyya de sang pandita"

\section{Artinya :}

"Adapun jalan untuk memperkuat hal itu disebut dengan trikaya paramartha, pegangan seorang pandita yang suci, bagiannya adalah: kāyikā wacīkascewa, manasikas tratiyaka, śubha karmma niyowyantu, trikayamiti kawyate tri kaya dibagi menjadi kaya, wak dan manah. Kaya adalah badan atau perbuatan, sedangkan wak adalah perkataan, dan manah adalah pikiran. Ketiganya itu harus selalu disthana-kan sesuai dengan perbuatan dan perilaku yang berdasarkan dharma dan ajaran agama Hindu oleh seorang pandita suci ${ }^{37}$ ".

Oleh karenanya konsep kesucian dalam yoga sesuai ajaran tri kaya parisudha dalam kitab dan sastra suci dapat memberikan gambaran bahwa karakter Hindu sebagai proses kristalisasi antara moralitas berdasarkan nilai, norma dan ajaran-ajaran agama Hindu merupakan bagian penting dalam pengembangan sumber daya umat. Karakter harus diawali dari penanaman pemahaman bahwa melalui perilaku yang baik akan membawa kepada dampak kesucian sehingga melalui perilaku yang baik maka karakter akan terbentuk. Yoga bukan hanya sekedar aktivitas olah raga biasa, namun jalan spiritualitas demi membangun kesucian untuk penyatuan sang jiwa yaitu atman dengan paramatman, jiwa semesta. Sehingga kesucian harus dilakukan dengan perilaku-perilaku yang mencerminkan kebaikan sehingga melatih tubuh dan pikiran agar suci merupakan bagian dari nilai karakter Hindu itu sendiri. Sehingga hal ini harus tertanam sejak dini dalam pikiran dan jiwa anak-anak.

\section{Karakter Religius Dalam Konsep Parhyangan pada}

${ }^{37}$ I Gusti Ayu Rai Arnita et al., Bhwwana Mahbah, Pūrwa Būmi Kamulan, Śiwa Śāsana, Sila Kramaning Aguron-Guron, 1st ed. (Denpasar: Kantor Dokumentasi Budaya Bali Provinsi Daerah Tingkat I Bali, 1996). 3 


\section{Ajaran Tri Hita Karana Pada Pelatihan Yoga}

Konsep karakter selanjutnya dalam esensi yoga adalah nilai karakter religius di mana dalam ajaran susila Hindu, karakter religius tercermin dari sradha dan bhakti yang tercermin dalam segala tindakan, di mana sradha dan bhakti ditunjukkan dalam keimanan dan keyakinan kepada Ida Sang Hyang Widhi Wasa. Sradha dan bhakti merupakan salah satu hal yang terpenting dalam kepercayaan umat Hindu.

Istilah sradha dan bhakti dalam ajaran agama Hindu memiliki padanan kata yang hampir sama dengan istilah iman dan takwa, sradha secara konseptual merupakan keyakinan terhadap keberadaan Brahman sebagai jiwa alam semesta yang merupakan sumber dari segala sumber kehidupan, sedangkan konsep bhakti adalah upaya, usaha dan tindakan tulus ikhlas yang ditujukan kepada Tuhan, sehingga konsep sradha dan bhakti dapat dimaknai sebagai keyakinan keagamaan kepada Tuhan yang ditunjukkan melalui perilaku-perilaku tanpa pamrih yang tujuan utamanya adalah persembahan kepada dan bersatu dengan Tuhan $^{38}$.

Konsep sradha sebagai karakter religiusitas merupakan salah satu esensi penting dalam ajaran agama Hindu yaitu Panca Sradha. Panca Sradha merupakan lima konsep keyakinan yang harus dipercaya dalam ajaran agama Hindu yaitu percaya kepada Brahman yaitu Tuhan sebagai pencipta alam semesta, Atman sebagai jiwa yang dalam diri manusia merupakan percikanpercikan kecil dari Brahman, Karmaphala percaya keyakinan akan setiap perbuatan baik dan buruk akan menciptakan sebuah hasil yang berdampak pada dirinya, punarbhawa bahwa hasil karma akan membuat manusia lahir berulang kali, dan Moksha adalah keyakinan sebagai tujuan akhir yang harus menjadi tujuan umat Hindu yaitu bersatunya atman dengan Brahman ${ }^{39}$. Yoga

\footnotetext{
${ }^{38}$ I Wayan Sukabawa, "Strategi Phdi Meningkatkan Sradha Dan Bhakti Umat Hindu Di Kota Palangka Raya Kalimantan Tengah," Vidya Samhita Jurnal Penelitian Agama 1, no. 2 (2015): 13-19, http://ejournal.ihdn.ac.id/ index.php/vs/article/view/82.

${ }^{39}$ I Gusti Ngurah Nala and I G.K. Adia Wiratmadja, Murddha Agama Hindu, 1st ed. (Denpasar: PT. Upada Sastra, 1991). 99-117
} 
sebagai salah satu jalan spiritualitas merupakan bagian dari kepercayaan Hindu itu sendiri sebagai salah satu cara dalam mencapai Tuhan yaitu moksha, yang tertuang dalam esensi catur marga yaitu empat jalan dalam mendekatkan diri kepada Tuhan yaitu Bhakti jalan persembahan tulus ikhlas, karma jalan berperilaku tanpa pamrih, jnana marga dengan mempelajari ilmu pengetahuan dan raja yoga marga yaitu melalui yoga dan semadhi untuk bersatu kepada Brahman.

Yoga secara esensi di dalamnya terkandung nilai-nilai pendidikan karakter yang bersifat religius. Nilai religiusitas ini tercermin dalam konsep Parhyangan merupakan konsepsi yang memiliki makna hubungan selaras antara manusia kepada Tuhan sebagai pencipta alam semesta ${ }^{40}$. Harus disadari bahwa alam semesta beserta isinya merupakan ciptaan Tuhan, bahkan atman sebagai jiwa dalam diri manusia merupakan bagian dari Tuhan, sehingga alam semesta berawal, berada dan berakhir dalam Tuhan. Sehingga sebagai bentuk penghormatan, dan pelaksanaan ajaran bhakti maka umat Hindu mengadakan hubungan yang harmonis dengan Tuhan, hubungan ini dilakukan dengan pendirian dan pembangunan tempat suci sebagai sthana dari Tuhan, serta dengan jalan merawat lingkungan sebagai salah satu esensi pelaksanaan bhakti kepada alam semesta, selain itu pula merawat diri sendiri serta menghormati manusia lain adalah bagian dari pelaksanaan bhakti kepada Tuhan karena dalam diri manusia terdapat atman percikan kecil dari Brahman.

Dalam pelatihan yoga, secara esensi untuk penyatuan kepada Tuhan, hubungan harmonis kepada Tuhan juga diwujudkan melalui aktivitas berdoa sebelum dan sesudah pelaksanaan Yoga seperti terlihat pada Gambar 6. Ini bukan hanya sebagai aktivitas rutinitas namun memang sebagai bentuk penghargaan, karena esensi yoga adalah kesucian maka harus diawali dengan perilaku yang suci pula. Berdoa juga merupakan salah satu upaya penanaman pendidikan karakter dalm perkembangan psikologi

${ }^{40}$ Putu Budiadnya, "Tri Hita Karana Dan Tat Twam Asi Sebagai Konsep Keharmonisan Dan Kerukunan," Widya Aksara Jurnal Agama Hindu 23, no. 2 (2018): 1-8, http://ejournal.sthd-jateng.ac.id/index.php/ WidyaAksara/article/view/38. 
keagamaan bagi anak-anak, melalui aktivitas berdoa maka anakanak diajarkan untuk selalu yakin kepada Tuhan sehingga secara langsung dan tidak langsung akan terbentuk akhlak mulia sebagai sebuah karakter dalam anak didik ${ }^{41}$.

Lebih dalam lagi, umumnya dalam aktivitas yoga terdapat beberapa doa yang umum digunakan oleh praktisi yoga dan pelaku yoga dalam mengawali dan mengakhiri. Doa-doa yang umum dilantunkan adalah mengucapkan pranawa Om, mantra gayatri, mantra guru dan mantra triyambhakam dan diakhiri dengan mantra asatoma. Pranawa mantra dalam Hindu adalah Om, Om merupakan mantra yang tercipta dari gabungan wijaksara a, u dan $\mathrm{m}$, yang kemudian menjadi aum, Om sebagai simbol dan sebagai lambang merupakan lambang dari Brahman $^{42}$. Doa yang dilakukan saat mengawali kegiatan yoga dengan pengucapan mantra om, memiliki makna pemuliaan dan penghormatan kepada Tuhan, yang secara konseptual merupakan proses internalisasi nilai-nilai religius penguatan sradha dan bhakti.

Mantra kedua yang dilantukan adalah mantra gayatri, gayatri mantra merupakan mantra suci yang merupakan pujian kepada Tuhan, yang slokanya sebagai berikut:

"Om, Om, Om, bhur bhuvah svah, tat savitur varenyam, bhargo devasya dhimahi dhiyo yo nah pracodayat"

Terjemahan :

"Om Sang hyang Widhi Wasa, yang menguasai ketiga dunia ini, engkau maha suci, sumber segala cahaya dan kehidupan, berikanlah budi nurani kami penerangan sinar cahaya-Mu yang Maha Suci"3".

\footnotetext{
${ }^{41}$ Perbowosari, "Optimalisasi Kecerdasan Spiritual Anak Melalui Yoga Asanas.”. 166-77

${ }^{42} \mathrm{Ni}$ Wayan Murniti, "Kajian Bentuk, Makna Dan Fungsi Kewangen Sebagai Produk Budaya Keagamaan," GENTA HREDAYA: Media Informasi Ilmiah Jurusan Brahma Widya STAHN Mpu 2, no. 2 (2018): 11-19, https://stahnmpukuturan.ac.id/jurnal/index.php/genta/article/view/433.

${ }^{43}$ I Gusti Ketut Widana, Etika Sembahyang Umat Hindu, ed. Ida Bagus Putu Eka Suadnyana, 1st ed. (Denpasar: UNHI Press, 2020), 49-50, http:// repo.unhi.ac.id/jspui/bitstream/123456789/1260/1/Etika Sembahyang Umat Hindu.pdf.
} 
Berdasarkan maknanya maka mantra gayatri ini merupakan pujian, pengakuan atas kuasa Tuhan sebagai pencipta alam semesta serta permohonan agar dianugerahkan pengetahuan, serta pikiran dan kesucian.

Mantra selanjutnya yang dilantunkan adalah mantra guru, mantra guru merupakan sloka suci bagian dari guru gita. 4, yaitu:

"Om, gururbrahmā gururviṣnugururdevo maheśvarah, guruh sākșāt param brahma tasmai śrīgurave namaḥ"

Artinya :

"Om adalah Tuhan, guru adalah Brahma, guru adalah Wisnu, guru adalah Siwa, guru adalah Brahman yang tertinggi, sujud dan hormat kami kepadamu guru" ${ }^{44}$.

Mantra terakhir dalam mengawali kegiatan yoga adalah mantra maha mrtyujaya mantram, yang merupakan mantra suci yang tertuang dalam kitab suci weda. Berdasarkan beberapa pustaka kajian disebutkan bahwa mantra ini memiliki manfaat diantaranya adalah untuk kesehatan yang sering digunakan sebagai terapi suara untuk relaksasi dan sakit pada leher ${ }^{45}$, selain itu pula mantra ini juga bertujuan untuk mensucikan dan menyehatkan tubuh serta pikiran ${ }^{46}$.

${ }^{44}$ Swami Śivānanda, Sarva Gītā Sāraḥ Intisari Semua Gītā, ed. Anak Agung Ngurah Prima Surya Wijaya, 1st ed. (Surabaya: Paramita, 2007). 4

${ }^{45}$ Ajay Bhardwaj, "Mantra Yoga: An Overview," Journal of Yoga and Physiotherapy 8, no. 2 (2019): 28-32, https://doi.org/10.19080/JYP. 2019.08.555737.

${ }^{46}$ Bali Yogitha et al., "Complimentary Effect of Yogic Sound Resonance Relaxation Technique in Patients with Common Neck Pain," International Journal of Yoga 3, no. 18-25 (2010), https://doi.org/10.4103/ 0973-6131.66774. 


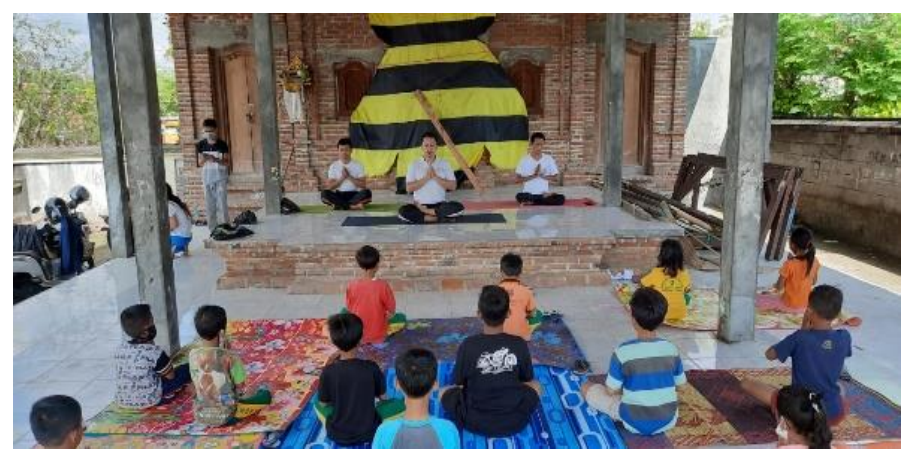

Sumber: Dokumentasi Tim Pengabdian

Gambar 6.

Mengawali yoga dengan Doa

Adapun sloka mantram dari maha mrityujaya mantram adalah sebagai berikut:

"Om Tryambakam Yajaamahe Sugandhim Pushti Vardhanam, Urvaarukamiva Bandhanaath Mrutyor Mukshiya Ma-Amritat"

Artinya :

"Marilah berbhakti, dan menghormat kepada Shiva dia yang memiliki mata ketiga, suci dan pencipta seluruh alam semesta, Semoga dibebaskan dari putaran kehidupan dan kematian serta dianugerahkan keabadian ${ }^{476 ،}$.

Pada akhir kegiatan juga dilanjutkan dengan mengakhiri kegiatan dengan melantukan doa diantaranya mantra asatoma dan sesanthi Om shanti, shanti, shanti. Adapun mantram asatoma merupakan mantram suci yang berasal dari sloka pada kitab Brhad Aranyaka Upanisad 1-3.28 sebagai berikut:

"Asato ma sad-gamaya, tamaso ma jyotir-gamaya, mrtyor ma amrtam gamaya, Om santih santih santih"

Terjemahannya :

"Om sebagai Tuhan, tuntunlah hamba dari jalan yang tidak benar menuju kebenaran, dari jalan kegelapan menuju cahaya yang

${ }^{47}$ Agus Dwiana, "Maha Mrtyum Jaya Mantram," Humas Bhuana Shanti, 2019, http://www.purabhuanashanti.com/2019/07/maha-mrtyum-jayamantram.html. 
terang, lepaskan kami dari kematian, untuk mencapai kepada kekekalan abadi"

"Om Shanti, shanti, shanti om" memiliki makna "Om sebagai Tuhan, semoga damai di hati, damai di dunia, damai selama-lamanya dalam lindungan- $\mathrm{Mu}^{48}$. Sehingga melalui doadoa tersebut maka konsep parhyangan sebagai penghormatan dan bhakti kepada Tuhan sebagai pencipta alam semesta di internalisasi kepada siswa pasrama, ini berguna untuk membangun pengetahuan dan pemaknaan nilai-nilai religiusitas kepada anakanak pasraman. Sehingga dalam dirinya timbul keyakinan untuk selalu menguatkan sradha dan bhakti kepada Brahman dan terbentuk karakter religius dan ahklak mulia dalam diri peserta didik ${ }^{49}$. Sehingga doa menjadi suatu pembiasaan yang penting untuk menanamkan nilai-nilai keagamaan dalam membentuk karakter $^{50}$.

Berdasarkan hal tersebut, maka dapat disimpulkan bahwa karakter religiusitas perwujudan konsepsi parhyangan sebagai aktualisasi nilai susila dalam aktivitas yoga bagi anak-anak pasraman dilakukan dengan melaksanakan pembiasaan berdoa dalam mengawali dan mengakhiri sebuah kegiatan, mengawali dengan permohonan agar selalu dilancarkan beraktivitas oleh Tuhan dan mengakhiri dengan tujuan mengucapkan terima kasih atas kelancaran aktivitas yang dilakukan sebagai bentuk penanaman nilai pendidikan religius untuk membentuk karakter dan akhlak mulia bagi anak-anak. Perilaku atau kegiatan berdoa ini juga sebagai bentuk aktualisasi pemahaman mengenai ajaran

${ }^{48}$ Ida Ayu Putu Indah Kartika DV, "Penerapan Pendidikan Agama Hindu Dalam Membentuk Karakter Anak Pada Tk Dwijendra Di Desa Dangin Puri Kangin, Kecamatan Denpasar Utara" (Universitas Hindu Indonesia Denpasar, 2018), 73, http://repo.unhi.ac.id/bitstream/123456789/100/1/I A Indah Kartika DV.pdf.

${ }^{49}$ Sri Marwiyati, "Penanaman Pendidikan Karakter Melalui Pembiasaan," ThufuLA: Jurnal Inovasi Pendidikan Guru Raudhatul Athfal 8, no. 2 (2020): 152-163, https://doi.org/10.21043/thufula.v8i2.7190.

${ }^{50}$ Ida Bagus Suradarma, "Pendidikan Agama Hindu Sebagai Landasan Pendidikan Moral Dan Etika," Jurnal Ilmiah Dinamika Sosial 3, no. 1 (2019): 16-36, https://doi.org/10.38043/jids.v3i1.1731. 
yoga juga diharapkan dapat dilaksanakan secara berkelanjutan oleh para sisya baik dilingkungan pasraman, keluarga dan di masyarakat, utamanya dalam setiap mengawali dan mengakhiri suatu kegiatan sehingga terbentuk keyakinan dan penguatan sradha dan bhakti.

\section{Panca Yama dan Nyama Brata dalam Yoga}

Ajaran susila terakhir dalam kegiatan pelatihan yoga sebagai penguatan pendidikan karakter adalah berkaitan dengan konsepsi ajaran panca yama brata dan panca nyama brata. Panca yama brata merupakan lima ajaran pengendalian dalam diri untuk meningkatkan kesucian dan kualitas diri yang terdiri atas ahimsa, brahmacari, satya, asteya dan awyawarahika ${ }^{51}$. Panca nyama brata merupakan lima ajaran pengendalian diri yang bertujuan dalam peningkatan kualitas rohani berpedoman kepada ajaran agama Hindu yaitu akrodha, sauca, guru susrusa, aharalagawa, dan apramada ${ }^{52}$.

Penguatan ajaran susila panca yama dan nyama brata sangat penting untuk ditanamkan kepada anak-anak, karena jika mengacu kepada pemaknaannya bahwa lima pengendalian diri tersebut bukan hanya untuk melatih tubuh sebagai wadah atman, namun juga untuk peningkatan kualitas rohani atman itu sendiri. Sehingga sesuai dengan tujuan yoga sebagai jalan penyatuan diri dengan Brahman dapat terwujud.

Ahimsa sebagai ajaran yang memiliki makna tidak menyakiti atau membunuh makhluk ${ }^{53}$, memiliki makna bahwa peserta didik harus memahami bahwa menyakiti makhluk hidup tidak diperkenankan apalagi menyakiti karena tindakan jahil semata

${ }^{51}$ I Wayan Jatiyasa, "Tutur Kesusilaan Sang Widura Dalam Gaguritan Widura Niti Wakya,” Widya Aksara 25, no. 1 (2020): 17-25, http://ejournal. sthd-jateng.ac.id/index.php/WidyaAksara/article/view/63.

${ }^{52}$ I Made Suweta, "Etika Dalam Teks Lontar Kumara Tattwa," Maha Widya Duta 3, no. 2 (2019): 1-10, http://jurnal.stahnmpukuturan.ac.id/ index. $\mathrm{php/duta/article/view/735.}$

${ }^{53}$ I Nyoman Sulastra, "Panca Yama Brata Sebagai Landasan Kepemimpinan Kelihan Desa Adat Desa Pecatu Kecamatan Kuta Selatan Kabupaten Badung," Pariksa 4, no. 2 (2020): 73-82, http://jurnal. stahnmpukuturan.ac.id/index.php/pariksa/article/view/1154. 
tentu akan sangat memberikan karma yang tidak baik, sehingga melalui ajaran ahimsa dalam yoga sebagai bentuk pengendalian untuk memberikan kedewasaan pemahaman bagaimana peserta didik dapat menyayangi semua makhluk. Dalam ajaran agama Hindu terdapat sesanti "vasudaiva kutumbakan" yang bermakna semua makhluk "umat manusia" bersaudara ${ }^{54}$. Sehingga melalui sasanthi tersebut dan ajaran ahimsa berguna untuk menguatkan pemahaman akan pentingnya tidak menyakiti dan menumbuhkan rasa kasih sayang, empati, menghormati kepada umat manusia, dan menaruh belas kasih kepada semua makhluk di alam semesta sebagai ciptaan Brahman itu sendiri.

Brahmacari sebagai pemahaman akan etika dalam mencari pengetahuan dan satya adalah kejujuran ${ }^{55}$, dalam ajaran yoga untuk menguatkan pemahaman akan pentingnya etika dalam mencari pengetahuan, seorang siswa harus memiliki etika dalam berguru karena guru dalam ajaran agama Hindu memiliki kedudukan yang sangat penting. Satya adalah kejujuran, bahwa karakter jujur merupakan bagian dari hal yang sangat diharapkan hadir dalam hidup manusia, melalui kejujuran maka setiap perbuatan yang dilakukan akan menghasilkan kebahagiaan. Sehingga melalui ajaran brahmacari dan satya dalam panca yama brata melalui pelatihan yoga untuk menguatkan karakter-karakter jujur dalam diri siswa.

Asteya adalah tidak mencuri dan awyawaharika tidak terikat duniawi, ajaran ini dalam yoga khususnya awyawaharika merupakan tujuan dari pelatihan yoga. Yoga dalam prosesnya untuk melatih tubuh dan pikiran berfungsi untuk mengendalikan indriya-indriya dan mencegah munculnya perilaku tidak baik, sehingga tidak terikat dengan kehidupan duniawi khususnya pengendalian akan kama (keinginan), dimana jika kama ini tidak dapat dikendalikan akan menyebabkan manusia tenggelam dalam kehidupan duniawi yang berakibat munculnya perilaku-perilaku yang dilarang dalam ajaran agama dan dharma. Karena

${ }^{54}$ A.A. Prima Surya Wijaya, Saya Bangga Beragama Hindu, ed. I Ketut Donder, 1st ed. (Surabaya: Paramita, 2010). 16

${ }^{55}$ Jatiyasa, "Tutur Kesusilaan Sang Widura Dalam Gaguritan Widura Niti Wakya.". 17-25 
kebahagian sejati yaitu moksha akan dapat terjadi bagi individuindividu yang sudah memahami akan hakikat dirinya, lepas dari pengaruh indriya, tidak terikat akan duniawi dan memahami ajaran dharma ${ }^{56}$. Sehingga ini memberikan pemahaman bahwa yoga sebagai pengendalian diri merupakan bagian dari penguatan pendidikan karakter bagi anak-anak untuk senantiasa tidak memiliki keinginan merampas hak milik orang lain, dan sedikit demi sedikit mengendalikan indriya dan tidak terlalu terikat akan kehidupan duniawi.

Ajaran yang cukup penting dalam panca nyama brata berkaitan dengan yoga untuk penguatan karakter peserta didik adalah guru susrusa dan sauca, guru susrusa memiliki makna penghormatan kepada guru dan sauca adalah suci baik lahir maupun batin ${ }^{57}$. Posisi guru dalam ajaran agama Hindu tidak hanya sekedar individu yang memberikan pengetahuan, namun dalam sisi spiritual fungsi guru begitu luhurnya. Bahkan dalam mantra mengenai guru, guru yang suci berbudhi baik diibaratkan sebagai tri murthi Brahma, Wisnu dan Siwa, begitu terhormatnya posisi guru tentu harus mendapatkan penghormatan yang layak oleh seorang sisya dalam masa brahmacari sehingga tidak dibenarkan bagi seorang sisya untuk menghina gurunya yang berbudhi luhur sebagaimana yang dijelaskan dalam sastra Guru Gita Sarah. 37 berikut:

"ekākșarapradātāram yo gurum naiva manyate, śunām yoniśatam gatvā canḍāleșvabhijāyate"

Artinya :

"Dia yang tidak memperdulikan, menghormati Guru yang telah memberi dia pengetahuan suci serta inisiasi kedalam ekaksara Om, dia akan lahir dari kandungan anjing selama beratus-ratus kelahiran, dan dilahirkan di antara orang-orang yang diasingkan ${ }^{58}$.

${ }^{56}$ Anak Agung Raka Asmariani, I Nyoman Suarka, and I Nengah Duija, "Eskatologi Dalam Teks Geguritan Atma Prasangsa (Kajian Teks Dan Konteks)," Jurnal Penelitian Agama Hindu 3, no. 1 (2019): 23-34, https://jayapanguspress.penerbit.org/index.php/JPAH/article/view/1171.

${ }^{57}$ Suweta, "Etika Dalam Teks Lontar Kumara Tattwa.". 1-10

58 Śivānanda, Sarva Gìtā Sāraḥ Intisari Semua Gītā. 13 


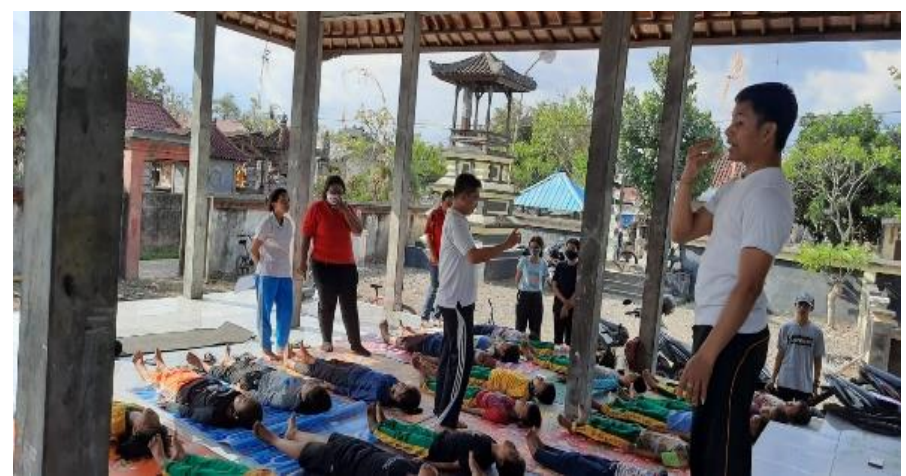

Sumber: Dokumentasi Tim Pengabdian, 2021

Gambar 7.

Sawasana dalam esensi santa rasa, rasa damai sebagai salah satu gerakan yoga

Sauca yang merupakan ajaran mengenai kesucian dalam lahir dan batin memberikan pemaknaan bahwa peserta didik dalam menjalani kehidupan brahmacarinya harus memiliki kesucian pikiran sehingga fokus aktivitasnya adalah mengisi diri dengan berbagai pengetahuan dan pengetahuan suci keagamaan, lepas dari keingginan keduniawian karena dalam masa brahmacari yang dituju adalah peningkatan kualitas pengetahuan bukanlah keduniawian. Sehingga guru susrusa dan sauca dalam panca nyama brata melalui kegiatan pelatihan yoga sangat penting untuk ditanamkan mengingat para peserta pelatihan adalah anakanak dalam masa brahmacari sehingga tertanam dalam dirinya etika-etika dalam belajar dan menghormati guru sebagai pemberi pengetahuan dan spiritualitas serta selalu menguatkan kesucian lahir dan batin.

\section{PENUTUP}

Secara garis besar berdasarkan hasil analisis data dan kajian berkaitan dengan permasalahan yang dikaji maka dapat disimpulkan bahwa kegiatan pelatihan yoga sebagai pengenalan pemahaman dan praktiknya sudah dipahami oleh sebagian besar sisya pelatihan, dan telah memahami esensi yoga bukan hanya 
sebatas pada gerakan-gerakan olah raga semata namun juga terdapat konsep-konsep keagamaan khususnya konsepsi spiritualllitas yoga sebagai salah satu ajaran catur marga yaitu salah satu jalan untuk mencapai Tuhan menurut Hindu. Berdasarkan hasil diskusi dan observasi terkait perilaku yang timbul dalam proses pelatihan yoga ini telah terjadi perubahan dimana pada awalnya yoga hanya diartikan sebagai gerakan-gerakan dinamis semata, namun telah diyakini terdapat konsepsi suci berdasarkan ajaran agama Hindu yang terkandung di dalamnya.

Dalam konsepnya, terdapat nilai-nilai pendidikan karakter yang berpedoman kepada ajaran susila dalam agama Hindu yaitu nilai spiritualitas, religius, disiplin, kejujuran dan lainnya yang berpedoman kepada ajaran Tri Kaya Parisudha, Parhyangan dan Panca Yama dan Nyama Brata. Nilai-nilai ini menjadi penting sebagai dasar dan pedoman dalam penguatan dan pengembangan pendidikan karakter bagi siswa pasraman, karena esensi dari pendidikan keagamaan Hindu adalah untuk membangun dan mengembangkan peserta didik yang tidak hanya terampil dalam pengetahuan-pengetahuan umum, namun juga dewasa secara spiritual dan emosional untuk menciptakan sumber daya umat Hindu yang unggul dan berkarakter.

Tidak dapat dipungkiri bahwa pelaksanaan kegiatan pelatihan yang dilaksanakan selama masa pandemi tentu dilakukan dengan kendala dan situasi yang terbatas karena harus melaksanakan protokol kesehatan secara ketat, seperti waktu yang diberikan sangat singkat pada setiap kegiatan sehingga tentu proses pelatihan dapat dikatakan kurang maksimal, namun dengan antusiasnya peserta pelatihan selama pelatihan sudah memberikan partisipasi sehingga kegiatan dapat berjalan seperti yang diharapkan. Semoga pandemi covid-19 segera usai sehingga kegiatan yang sangat penting semacam ini dapat dilakukan kembali dalam suasana yang lebih maksimal. 


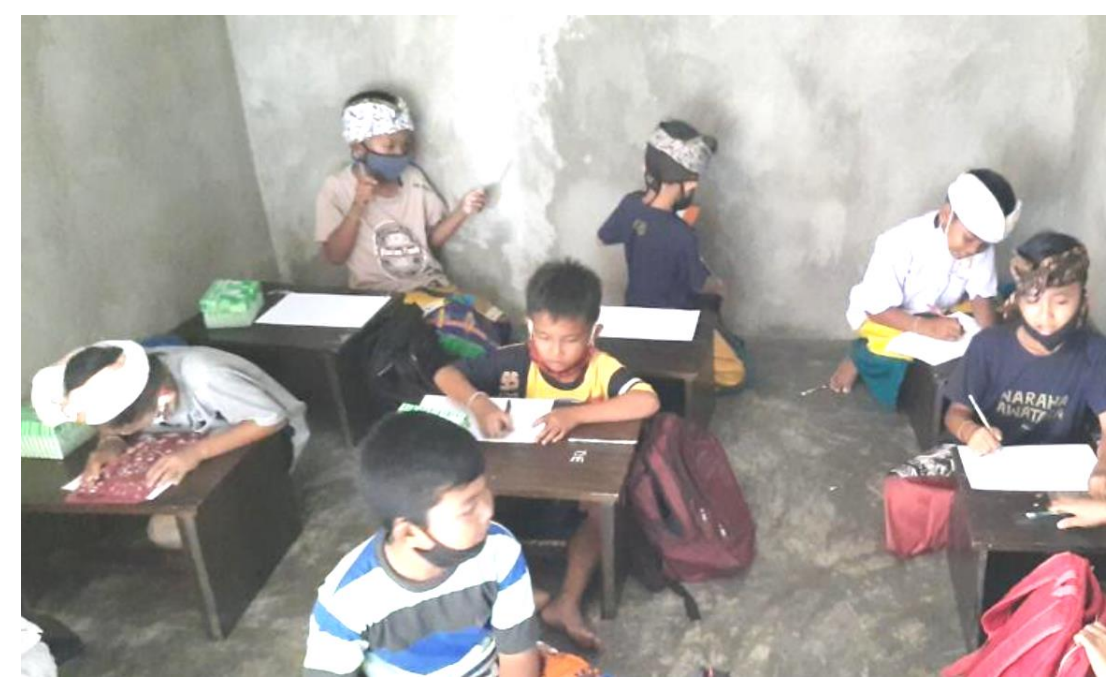

\section{DAFTAR PUSTAKA}

\section{Buku}

Arnita, I Gusti Ayu Rai, I Gede Sura, I Wayan Dunia, Ida Bagus Kade Sindu, I Gusti Ketut Dalem, and I Wayan Sukayasa. Bhuwana Mahbah, Pūrwa Būmi Kamulan, Śiwa Śāsana, Sila Kramaning Aguron-Guron. 1st ed. Denpasar: Kantor Dokumentasi Budaya Bali Provinsi Daerah Tingkat I Bali, 1996.

Creswell, John W. Penelitian Kualitatif Dan Desain Riset Memilih Di Antara Lima Pendekatan. Edited by Saifuddin Zuhri Qudsy. 3rd ed. Yogyakarta: Pustaka Pelajar, 2015.

Elmubarok, Zaim. Membumikan Pendidikan Nilai Mengumpulkan Yang Terserak, Menyambung Yang Terputus, Dan Menyatukan Yang Tercerai. Edited by Dudung Rahmat Hidayat. 3rd ed. Bandung: ALFABETA, 2013.

Emzir. Metodologi Penelitian Kualitatif Analisis Data. 1st ed. Jakarta: Rajawali Press, 2014.

Graham, Gordon. Teori-Teori Etika. Edited by Muhammad Rizal. 1st ed. Bandung: Nusa Media, 2014.

Kadjeng, I Nyoman, and dkk. Sarasamuscaya Dengan Teks Bahasa 
Sansekerta Dan Jawa Kuna. 1st ed. Surabaya: Paramita, 1997.

Nala, I Gusti Ngurah, and I G.K. Adia Wiratmadja. Murddha Agama Hindu. 1st ed. Denpasar: PT. Upada Sastra, 1991.

Pudja, M. Bhagawad Gītā (Pañcama Veda). Edited by I Wayan Maswinara. 1st ed. Surabaya: Paramita, 2013.

Setyosari, Punaji. Desain Pembelajaran. Edited by Bunga Sari Fatmawati. 1st ed. Jakarta: PT Bumi Aksara, 2020.

Sugiyono. Metode Penelitian Kualitatif Untuk Penelitian Yang Bersifat: Eksploratif, Enterpretif, Interaktif Dan Konstruktif. Edited by Sofia Yustiyani Suryandari. 1st ed. Bandung: ALFABETA, 2020.

. Metode Penelitian Kuantitatif, Kualitatif Dan $R \& D$. 1 st ed. Bandung: ALFABETA, 2016.

Śivānanda, Swami. Sarva Gītā Sārah Intisari Semua Gìtā. Edited by Anak Agung Ngurah Prima Surya Wijaya. 1st ed. Surabaya: Paramita, 2007.

Tung, Khoe Yao. Desain Instruksional Perbandingan Model Dan Implementasinya. Edited by Venan. 1st ed. Yogyakarta: ANDI, 2017.

Wijaya, A.A. Prima Surya. Saya Bangga Beragama Hindu. Edited by I Ketut Donder. 1st ed. Surabaya: Paramita, 2010.

\section{Artikel}

Asmariani, Anak Agung Raka, I Nyoman Suarka, and I Nengah Duija. "Eskatologi Dalam Teks Geguritan Atma Prasangsa (Kajian Teks Dan Konteks)." Jurnal Penelitian Agama Hindu 3, no. 1 (2019): 23-34.

https://jayapanguspress.penerbit.org/index.php/JPAH/article/view $/ 1171$.

Asniati, Asniati, Sudarmi Suud Binasar, and Jahada Jahada. "Pengaruh Penggunaan Internet Terhadap Kenakalan Remaja (Siswa)." Jurnal Ilmiah Bening: Belajar Bimbingan Dan Konseling 4, no. 1 (2020): 17-26. https://doi.org/10.36709/bening.v4i1.10485.

Astuti, Ketut Wendi. "Olah Raga, Olah Rasa Dan Olah Pikiran Melalui Asana Yoga." Jurnal Bakti Saraswati Vol. 08, no. 02 (2019): 
179-91.https://e-journal.unmas.ac.id/index.php/baktisaraswati/ article/view/617.

Bhardwaj, Ajay. "Mantra Yoga: An Overview." Journal of Yoga and Physiotherapy 8, no. 2 (2019): 28-32. https://doi.org/10.19080/ JYP.2019.08.555737.

Budiadnya, Putu. "Tri Hita Karana Dan Tat Twam Asi Sebagai Konsep Keharmonisan Dan Kerukunan." Widya Aksara Jurnal Agama Hindu 23, no. 2 (2018): 1-8. http://ejournal.sthd-jateng.ac.id/ index.php/WidyaAksara/article/view/38.

Dayuh, I Nyoman. "Pengetahuan Spiritual Yoga." Jurnal Penjaminan Mutu 1, no. 2 (2016): 79-90. https://doi.org/10.25078/jpm. v1i2.53.

Hudi, Ilham. "Pengaruh Pengetahuan Moral (Moral Knowing) Terhadap Perilaku Moral (Moral Action) Pada Siswa SMP Negeri Kota Pekanbaru Berdasarkan Pendidikan Orangtua." Jurnal Moral Kemasyarakatan 2, no. 1 (2017): 30-44. https://doi.org/ 10.21067/jmk.v2i1.1698.

Jalil, Abdul. "Karakter Pendidikan Untuk Membentuk Pendidikan Karakter." Nadwa: Jurnal Pendiidkan Islam 6, no. 2 (2012): 175-93. https://doi.org/10.21580/nw.2012.6.2.586.

Jatiyasa, I Wayan. "Tutur Kesusilaan Sang Widura Dalam Gaguritan Widura Niti Wakya." Widya Aksara 25, no. 1 (2020): 17-25. http://ejournal.sthdjateng.ac.id/index.php/WidyaAksara/article/view/63.

Kartika DV, Ida Ayu Putu Indah. "Penerapan Pendidikan Agama Hindu Dalam Membentuk Karakter Anak Pada Tk Dwijendra Di Desa Dangin Puri Kangin, Kecamatan Denpasar Utara." Universitas Hindu Indonesia Denpasar, 2018. http://repo. unhi.ac.id/ bitstream/123456789/100/1/I A Indah Kartika DV.pdf.

Kinasih, Arum Sukma. "Pengaruh Latihan Yoga Terhadap Peningkatan Kualitas Hidup." Buletin Psikologi 18, no. 1 (2010): 1-12. https://doi.org/10.22146/bpsi.11531.

Madja, I Ketut. "Makna Astangga Yoga Patanjali." Guna Widya: Jurnal Pendidikan Hindu 7, no. 1 (2020): 87-96. https://doi.org/ 10.25078/gw.v7i1.1278.

Marwiyati, Sri. "Penanaman Pendidikan Karakter Melalui Pembiasa- 
an." ThufuLA: Jurnal Inovasi Pendidikan Guru Raudhatul Athfal 8, no. 2 (2020): 152-163. https://doi.org/10.21043/thufula. v8i2.7190.

Mayeni, Riska, Okviani Syafti, and Sefrinal. "Dampak Perkembangan Teknologi Dikalangan Remaja Dilihat Dari Nilai-Nilai Karakter." Turast: Jurnal Penelitian Dan Pengabdian 7, no. 2 (2019): 23946. https://doi.org/10.15548/turast.v7i2.1298 (Diterima:

Mertayasa, Ketut. "Pengaruh Pelatihan Yoga Asana (Suryanamaskar) Terhadap Kelentukan Dan Kapasitas Vital Paru." Ilmu Keolahragaan Undiksha 1, no. 1 (2013): 1-8. https://doi.org/ 10.23887/ jiku.v1i1.1578.

Murniti, Ni Wayan. "Kajian Bentuk, Makna Dan Fungsi Kewangen Sebagai Produk Budaya Keagamaan." GENTA HREDAYA: Media Informasi Ilmiah Jurusan Brahma Widya STAHN Mpu 2, no. 2 (2018): 11-19. https://stahnmpukuturan.ac.id/jurnal/ index. php/genta/article/view/433.

Nur'aini, Ratna Dewi. "Penerapan Metode Studi Kasus Yin Dalam Penelitian Arsitektur Dan Perilaku." INERSIA: Lnformasi Dan Ekspose Hasil Riset Teknik Sipil Dan Arsitektur 16, no. 1 (2020): 92-104. https://doi.org/10.21831/inersia.v16i1.31319.

Nuryamin. "Implementasi Filsafat Perenial Dalam Pembelajaran." Jurnal Aqidah-Ta 5, no. 1 (2019): 49-61. https://doi.org/10.24252/aqidahta.v5i1.7884.

Panggraita, Gilang Nuari, Sugiharto, and Tommy Soenyoto. "Pengaruh Latihan Hatha Yoga Dan Kapasitas Vital Paru Terhadap Penurunan Lemak Tubuh." Journal of Physical Education and Sports 6, no. 1 (2017): 29-35. https://doi.org/10.15294/jpes. v6i1.17318.

Paramartha, Wayan, and I Wayan Suka Yasa. "Mengungkap Model Pendidikan Hindu Bali Tradisional Aguron-Guron." Mudra 32, no. 1 (2017): 131-40. https://doi.org/10.31091/mudra.v32i1.92.

Perbowosari, Heny. "Optimalisasi Kecerdasan Spiritual Anak Melalui Yoga Asanas.” Kamaya: Jurnal Ilmu Agama 1, no. 2 (2018): 166-77. https://jayapanguspress.penerbit.org/index.php/kamaya/ article/view/77.

Prihatsanti, Unika, Suryanto Suryanto, and Wiwin Hendriani. "Menggunakan Studi Kasus Sebagai Metode Ilmiah Dalam Psikologi." 
Buletin Psikologi 26, no. 2 (2018): 126-36. https://doi.org/ 10.22146/buletinpsikologi.38895.

Sentana, Gek Diah Desi. "Penanaman Konsep Tri Kaya Parisudha Dalam Tradisi Mareraosan." Guna Widya: Jurnal Pendidikan Hindu 4, no. 2 (2017): 33-39. https://doi.org/10.25078/ gw.v4i2. 1056.

Setyaningsih. "Implementasi Pembelajaran Pendidikan Agama Hindu Dalam Pembentukan Karakter Anak Hindu Di Sekolah Dasar Negeri Surakarta." Cetta: Jurnal Ilmu Pendidikan 2, no. 2 (2019): 297-332. https://jayapanguspress.penerbit.org/index.php/ cetta/article/view/272.

Sudarsana, I Ketut. "Ajaran Satya Dan Dharma Dalam Membentuk Karakter Keluarga Hindu Di Desa Peguyangan Kangin Kota Denpasar." JSSH (Jurnal Sains Sosial Dan Humaniora) 2, no. 2 (2018): 289-302. https://doi.org/10.30595/jssh.v2i2.2188.

Sukabawa, I Wayan. "Strategi Phdi Meningkatkan Sradha Dan Bhakti Umat Hindu Di Kota Palangka Raya Kalimantan Tengah.” Vidya Samhita Jurnal Penelitian Agama 1, no. 2 (2015): 13-19. http://ejournal.ihdn.ac.id/index.php/vs/article/view/82.

Sukerni, Ni Made. "Pendidikan Karakter Dalam Lontar Tutur Silakramaning Aguron-Guron." Guna Widya: Jurnal Pendidikan Hindu 4, no. 1 (2017): 81-90. https://doi.org/10.25078/ gw.v4i1. 391.

Sukrawati, Ni Made. "Nilai Didaktis Upacara Pacaruan Sasih Kaenem Di Pura Pasek Ngukuhin, Desa Pakraman Tonja, Kota Denpasar." Dharmasmrti: Jurnal Ilmu Agama Dan Kebudayaan 17, no. 2 (2017): 86-97. https://doi.org/10.32795/ds.v17i02.94.

Sulastra, I Nyoman. "Panca Yama Brata Sebagai Landasan Kepemimpinan Kelihan Desa Adat Desa Pecatu Kecamatan Kuta Selatan Kabupaten Badung." Pariksa 4, no. 2 (2020): 73-82. http:// jurnal.stahnmpukuturan.ac.id/index.php/pariksa/article/view/115.

Sulhan, Muhammad. "Pendidikan Karakter Berbasis Budaya Dalam Menghadapi Tantangan Globalisasi." Visipena Journal 9, no. 1 (2018): 159-72. https://doi.org/10.46244/visipena.v9i1.450.

Suradarma, Ida Bagus. "Pendidikan Agama Hindu Sebagai Landasan Pendidikan Moral Dan Etika." Jurnal Ilmiah Dinamika Sosial 3, 
no. 1 (2019): 16-36. https://doi.org/10.38043/jids.v3i1.1731.

Suweta, I Made. "Etika Dalam Teks Lontar Kumara Tattwa." Maha Widya Duta 3, no. 2 (2019): 1-10. http://jurnal.stahnmpukuturan. ac.id/index.php/duta/article/ view/735.

Utama, I Wayan Budi, and Ida Bagus Suatama. "Ketika Yoga Sebagai Gaya Hidup." Dharmasmrti: Jurnal Ilmu Agama Dan Kebudayaan 18, no. 1 (2018): 16-24. https://doi.org/ 10.32795/ ds.v1i18.111.

Widana, I Gusti Ketut. Etika Sembahyang Umat Hindu. Edited by Ida Bagus Putu Eka Suadnyana. 1st ed. Denpasar: UNHI Press, 2020. http://repo.unhi.ac.id/jspui/bitstream/123456789/1260/1/Etika Sembahyang Umat Hindu.pdf.

Yogitha, Bali, R Nagarathna, Ebnezar John, and HR Nagendra. "Complimentary Effect of Yogic Sound Resonance Relaxation Technique in Patients with Common Neck Pain." International Journal of Yoga 3, no. 18-25 (2010). https://doi.org/10.4103/ 0973-6131.66774.

\section{Web}

Dwiana, Agus. "Maha Mrtyum Jaya Mantram." Humas Bhuana Shanti, 2019. http://www.purabhuanashanti.com/2019/07/maha-mrtyumjaya-mantram.html. 